\title{
THE TRUST PROBLEM IN THE LIGHT OF SOME RECENT DECISIONS
}

The unusual amount of hostile criticism that followed the publication of the decision in the International Harvester Case was surprising. Reference is not made to the reviews in various legal publications, for either favorable or unfavorable analysis of an opinion of such a character might be more or less anticipated. But that the daily press at large and the weekly and monthly publications of the country should rush to the defense of a corporation, one of the largest and most powerful in the country, and that their comment should have been unsparing in finding fault with the reasons and conclusions of a federal court in attempting to destroy such an organization, was at least unexpected. There had been so much popular acclaim during the last decade as decision after decision has been handed down giving interpretation to the Sherman Act and through such interpretation decreeing the breaking up and dissolution of holding companies and so-called trusts and big business in general, that it must have made a casual observer pause and wonder why there was such a sudden change. After all, the daily press instead of attempting to guide the public, endeavors to ascertain what public sentiment is, and that once found, it cautiously caters to it. If a large section of the press of the country approves or disapproves of any particular act we may take it for granted that the reason for such approval or disapproval is because it believes that the public itself possibly in a subconscious manner has first approved or disapproved of the very act. So one is led to believe that the criticism in the press relating to the Harvester decision must have gone deeper and must have been more than merely the expression of a few handfuls of men writing in the seclusion of their editorial offices; that it reflected, in fact, the feelings or views of that part of the country at large which had given thought to the commercial, economic and legal problems that this decision presented.

To believe for a moment that a decision of this character is merely an analysis of a legal problem would be a fundamental error. Indeed the country at large is concerned but little with the legal intricacies and judicial ingenuity that may be shown by the court. The public realizes, however, that a decision of 
such a character interprets the policy of our government on the most vital economic problem of the day. It realizes that the legal side of these cases has been so minimized and the economic side so emphasized that the last congress largely took out of the hands of the court the power to shape this policy and determined that in the future a commission composed not of lawyers, but of men from all walks in life should in these matters be the arbiters.

The courts, too, have not been slow in recognizing this fact, for in their more recent decisions they are constantly adverting to what the public welfare demands and apparently are grounding their decisions on their conception as to what will be for its benefit. Thus, in the case of United States $v$. Great Lakes Towing Company, ${ }^{1}$ the court expressly refused to dissolve the combination there, for the reason that it would be against the public interests to do so and said: "Merely enjoining further operation by the towing company would injure rather than benefit the public by depriving it of the present service pending the reorganization of a new and sufficient service." And again in the case of United States v. Keystone Watch Case Company," the court says: "We see no sufficient evidence that the public interest requires us to break up the existing corporate entity." (p. 5I9.) So, too, in the case of Nash v. United States, ${ }^{3}$ the court again expressed this belief when it used the following words: "Those cases may be taken to have established that only such contracts and combinations are within the act as, by reason of intent or the inherent nature of the contemplated acts prejudiced the public interests by unduly restricting competition or unduly obstructing the course of trade."

It then becomes the duty of jurists and judges to ascertain what this public welfare is, for it is becoming quite apparent that the courts who may have the courage to expound and interpret the law in this spirit will be regarded as judges of independent vision and thought and as men who have laid down a new judicial foundation upon which our commercial greatness can safely grow. If decisions, however, are to rest on this basis it is time for the courts to break away from the narrow interpretation of the Sherman Act. If the public welfare is

\footnotetext{
${ }^{2} 217$ Fed. 656, 660.

2218 Fed. 502. See also United States v. American Tobacco Company, 221 U. S. I06, 179.

${ }^{3} 229$ U. S. 373,376 .
} 
to be conserved and promoted, as far as it may lay in the hands of the court, then decisions can no longer be justified that are merely supported by the precedents of the past. To determine what is for the public welfare it will be essential that the newer decisions relating to big business be based on a broad and thorough comprehension of the fundamental principles of economics.

It was Achille Loria $^{4}$ who pointed out, proved and settled for all times that laws are shaped, formed and evolved by the economic condition under which we live. Unconsciously the courts have added their testimony to this great truth by remarks they have let drop from time to time. When, in years gone by, one court after another stated that the common law as it existed in England was adopted by the colonies so far only as its principles were suitable to their condition, they were giving an illustration of Achille Loria's maxim.

It has often been the case that an old statute or a law expounded by an ancient decision has been made to square with a new environment and economic condition of a more modern life by a court giving some unexpected and new interpretation to an old law. A century after the courts had determined the extent to which the common law of England had been adopted by the colonies, the highest court in this land in the decisions in the Standard Oil Company and American Tobacco Company Cases $^{6}$ again illuminated the Loria truism. For even the laws and statutory enactments of congress had to bend and shape themselves, when necessary, in order to harmonize with a newer economic life. It was in these cases that the court held that Sections I and 2 of the Sherman Act had to be construed in the light of reason and the view taken was that, although the Act provided "Every contract, combination in the form of trust or otherwise, or conspiracy in restraint of trade or commerce among the several States, or with foreign nations, is hereby declared to be illegal,"

${ }^{4}$ Achille Loria, Economic Foundations of Society.

${ }^{\circ}$ Wheaton \& Donaldson v. Peters \& Gregg, 8 Peters 858 . See also Reno Sinelting, Milling \& Reduction Works v. C. C. Stevenson, 4 L. R. A. 64,20 Nev. 269 . At p. 64 the court, after citing a number of authorities, says: "From these authorities we assume that the applicability of the common law rule relating to the physical characteristics of the state should be considered. Its inapplicability to the Pacific states as shown in Atkinson v. Peterson, 87 U. S. (20 Wall) 5 Io applies forcibly to the State of Nevada."

${ }^{\circ} 221$ U. S. I; 221 U. S. 106. 
nevertheless a reasonable construction must be given to the words "restraint of trade"; that they "did not embrace all those normal and usual contracts essential to individual freedom and the right to make which was necessary in order that the course of trade might be free." Yet, as a result of the reasonable construction which was placed upon the statute, it was pointed out that the generic designation of the first and second sections of the law, when taken together, embraced every conceivable act which could possibly come within the spirit or purpose of the prohibitions of the law, without regard to the garb in which such acts were clothed. ${ }^{7}$

No one will object to the conclusion that the supreme court reached in those cases or find fault with the reasons for its decision. One, however, may feel that the reason why the act had to be interpreted in the light of reason was because of the fundamental drastic economic upheaval that would have followed a strict interpretation of the statute.

To modify the expression so frequently found in the older reports relating to the common law, we might say that the supreme court held in this case that the Sherman Act was the statutory law only so far as it remained applicable to our economic conditions. Is it too violent a presumption to infer that the supreme court probably unconsciously was giving expression to the economic business necessities of the day?

Can anything be clearer than that the history of legislation regulating business has followed the history of the economic development of the country and that neither laws nor decisions interpreting it will give satisfaction unless there is a clear and thorough comprehension of the necessities of commerce. We may be sure that without the great concentration of capital there never would have been a Sherman Act on the statute books and we may also feel certain that had the congressmen and representatives two decades ago had a clearer and more thorough knowledge of the basic laws of commerce, that if they had more closely perceived what would have proved beneficial or detrimental to the public, the Sherman Act would have been better drawn and would have absolved our courts from the necessity of trying to make it square with the needs of everyday business life.

It must be expected that, as decisions are handed down from time to time which endeavor to formulate rules under which

\footnotetext{
${ }^{7} 221$ U. S. I80.
} 
business may be carried on, the public will applaud or withhold their approval as they may conceive themselves to be benefited or injured by the new rule regulating the game. If the decision in the International Harvester Case met with so much adverse criticism from lay minds, it is well worth while to endeavor to ascertain the cause of this dissatisfaction. Such dissatisfaction undoubtedly must indicate that the decision is somewhere at variance with the vital business necessities of the day and we must all realize that sooner or later the law will shape itself either through statute or by decisions in court so as to conform to the public welfare. This question may be asked with all the greater propriety because in several decisions more recently handed down by federal courts of equal standing results practically diametrically opposite have been reached. ${ }^{8}$

Let us then examine the International Harvester decision.' Why was the corporation held to be illegally organized? What did the court hold? The court ascertained that five large competing companies in the year 1902 combined; that since then the new company, among other things, manufactured from 80 to 85 per cent of the binders, mowers, and reapers and rakes, produced in this country. In the majority opinion, the court found "that the treatment by the corporation of its smaller competitors had been fair and just" (p. 993) and that "in the main the business conduct of the company towards its competitors and the public has been honorable, clean and fair." (p. I002.) In his dissenting opinion, Judge Sanborn expressly found from the facts, which are nowhere contradicted, "that the consistent and persistent purpose, policy, rule of action, and practice of the defendants has been and is to avoid and prevent all acts and methods unfair, unjust, or oppressive towards their competitors, to leave competition with them free, to give to them full and fair opportunities to secure shares of the trade and business in which they are all engaged, and to carry on their trade honestly, justly, and fairly." (p. roo8.) He also found that the price was substantially the same in I9I2 for a better machine that it was for a poorer one in 1902 ; that the company had not limited the production of machinery, deteriorated the quality, or decreased the wages of the laborers employed to make them, or the prices paid for the materials required to con-

\footnotetext{
${ }^{*} U$. S. v. Great Lake Towring Company, 2I7 Fed. 656; U. S. v. Keystone Watch Case Company, 218 Fed. 502.

${ }^{9} 214$ Fed. 987.
} 
struct the the opposite of these things. (p. I009.) It appeared from this dissenting opinion that neither consumers, purchasers of the goods of the Harvester Company, its employes or the jobbers with whom they did business had any real complaint against its business methods.

Why then did the court dissolve a big corporation carrying on its business in this admittedly honorable way?

The reasons given were two.

The first was that some ten years prior to the filing of the bill, the company had been formed by the joining together of some five independent companies; that this resulted at least in the elimination of competition between the five companies and that the contract that these independent companies entered into to form that combination was therefore illegal.

"We think it may be laid down as a general rule that if companies could not make a legal contract as to prices or as to collateral services they could not legally unite, and, as the companies named did in effect unite, the sole question is as to whether they would have agreed on prices and what collateral services they would render, when their companies were all prosperous and they jointly controlled 80 to 85 per cent of the business in that line in the United States. We think they could not have made such an agreement." (p. 999.)

The second reason given was that the company did not represent a natural normal growth.

"The International Harvester Company is not the result of the normal growth of the fair enterprise of an individual, a partnership or a corporation. On the contrary, it was created by combining five great competing companies which controlled more than 80 per cent of the trade in necessary farm implements, and it still maintains a substantial dominance. That is the controlling fact; all else is detail." (p. IOor.)

These are the reasons given for dissolving the company. Was the public justified in refusing to accept them as valid? Did the court consider the public welfare, in announcing them?

A reader may readily say that it makes very little difference whether a decision were distasteful or not to the public; that the only question involved was whether it was sound legally. The point that the writer is trying to make, however, is that 
in cases of this character no decision can be legally sound that is not fundamentally correct from an economic point of view; that correct economics will be the hub on which the final decisions regulating big business will turn, and the court will find that those decisions that disregard the economic welfare of the community will ultimately be swept away as vicious and inherently unsound; that, moreover, the courts are recognizing this fact more and more every day. Nowhere in the Harvester opinion can any reference be found to the thought that the leading economists in this country from time to time have given to these matters. The court minimized the public welfare; the illegality of a contract in 1902 is magnified. This is the vice of the theory on which the decision is based.

That an illegal act was done in I902 when the five companies combined is probably correct. That act was probably an infraction of the Sherman Act. But the suit was not brought for ten years thereafter and in the decision the court clearly says that no complaint is found with the way in which the business was conducted for the seven years preceding the filing of the suit. What difference did it make to the public whether a decade ago five large corporations were guilty of illegally combining so long as during the intervening period neither the public nor any part of it had been hurt? What difference did it make what happened ten years ago so long as the business of the competitors of the company had in the meantime remained unrestrained and had a free field in which to develop their own business and so long as the consuming public received a better product at the same price?

If Judge Smith is correct in his reasoning that there is no such thing as a statute of limitations against a company illegally organized; if he is correct when he says that the government may bring suit at any time after an illegal act has been committed, no matter how fair the company may have been in its dealings since then, one must ask himself what businesses, if any, are safe from a dissolution. For it must be remembered that, after all, the courts have held again and again that the Sherman Act merely gave expression to the English common law relating to monopolies and restraint of trade. ${ }^{10}$ Consequently, if the decision of the International Harvester Case is the correct exposition of the common law, any consolidation, no

${ }^{10}$ U. S. v. American Tobacco Co., 22I U. S. I06, I79. 
matter how small it may have been, or any act that tended to unreasonably restrain trade, no matter when the agreement was made, or when the act took place, whether ten years or a century ago, was illegal and that illegality persists and is sufficient for any court to order the dissolution of such business at any time. This becomes a very serious consideration when one realizes that almost every business that exists, or has survived for a period of fifty years, at some time or other probably did something that at least in some minor way tended to monopolize the industry that it may have been engaged in, or tended to restrain trade. If Judge Smith is correct, then all of these businesses should be broken up, for the great and grave consideration is whether any illegal contracts were made at any time by which trade was unreasonably restrained. The opinion is not based on the finding as to whether the company has become a public menace. It is based on the fact that at the time of the organization of the company an illegal act was entered into by the five constituent companies. It is submitted that should the courts carry this doctrine to its logical conclusion it would bring about an economic revolution. Is it not apparent that what the public is concerned with is the illegality of the present and not with the possible illegality that may have died decades ago? The Sherman Act was probably directed against specific evils that may or may not be produced through combination. It was aimed against the attempt to either monopolize or restrain trade. The combination that neither does one nor the other and does not menace the public welfare by crushing its competitors and coercing the public in all probability does not transgress the law, and when the only crime of which it was guilty was that of having done an illegal act at its inception it hardly merits the punishment of being destroyed.

Even according to later decisions the mere fact that a contract made in 1902 tended to restrain competition is not sufficient proof that it actually did restrain competition. This at least was the holding of the court in the Keystone Watch Case, where the facts were much stronger in favor of the government with respect to oppressive practices than in the Harvester Case. In the former case the court said:

"But another and ordinarily a better way of determining whether a course of conduct under examination is in restraint of trade is sometimes available, and that is by considering its actual effect. It goes without saying 
that such a test can only be applied after the course in question has actually been carried out in some degree, has actually been tried by experience; and this leads to the further question: When should the standard of reasonableness be applied? Evidently this will depend on the time when the question is submitted for decision. This time may either precede the proposed course of conduct, or it may follow the beginning of such a course so quickly that nobody of experience, or no sufficient body, has yet come into existence. In that event the nature of things compels the court to enter the field of prophecy, or of probable anticipation. In such a situation, nothing else can be done. A court can only deal with the situations that are laid before it, and in the case supposed it must avail itself of whatever light may be had, and must exercise its best judgment with such aid as may be at hand. But, if the suit be deferred until the lapse of time and the actual effect of the conduct complained of have permitted facts to accumulate and have tried the project in question by the test of experience, we can hardly doubt that prophecy or probable anticipation should be considered inferior in force to the evidence of what has actually taken place."11

Strange enough to say, however, Judge Smith in the Harvester opinion contradicts himself, for though he directs the company to be dissolved because it was originally brought about by five different organic companies combining, nevertheless he states:

"There is no limit under the American law to which a business may not independently grow, and even a combination of two or more businesses, if it does not unreasonably restrain trade, is not illegal, but it is the combination which unreasonably restrains trade that is illegal, and if the parties in controversy have eighty or eighty-five per cent. of the American business and by the combination of the companies all competition is eliminated between the constituent parts of the combination then it is in restraint of trade within the meaning of the statute under all of the decisions." (p. I000.)

How two companies could be combined without eliminating the competition between the constituent parts is a mystery. If the competition were not eliminated the two constituent companies would not be combined. What then is the essential difference between two or five companies being brought together? The competition in either event is eliminated and the illegal act must

${ }^{11} U$. S. v. Keystone Watch Case Co., 218 Fed. 502, 517. 
therefore persist, and where would the courts say that reasonable restraint ends and unreasonable restraint begins? What percentage of the trade may an organization have before it becomes a monopoly? The United States Steel Company maintains it has only between fifty and sixty per cent of the entire business of the country. Does this lower percentage absolve it from guilt? Other companies against which the government has brought suit claim to have had less than forty per cent. Where do the courts draw the line? In industry there must be an elasticity and it is safe to say that no "rule of the thumb" can settle or solve this enigma.

It is not disputed that if a combination like the Harvester Company or the Keystone Watch Company were about to be formed to-day the court might in a proper proceeding order its dissolution, for it might well be urged that the purpose of the contract was to form a monopoly and that trade should be restrained. It is submitted, however, that because the court could dissolve an organization at the time of its formation it would not have the same right to do so a decade thereafter when it had been demonstrated and shown from experience and by the testimony of its competitors and by the statistics relating to the particular trade that no such restraint had been exercised. In the one instance there might be a fair presumption that a great injustice to the competitors of such a business, as well as to the public, were to be perpetrated. After a decade had gone by, however, the grounds for any such presumption in the light of experience could no longer exist. Ten years thereafter evidence is available in order to ascertain what the purpose and objects of the organization were. Were the purpose and objects merely to secure efficiency, to reduce costs, to eliminate waste and duplication-consequences that naturally follow a more highly organized business-then no such presumption could any longer live. The presumption would have to give way to the actual facts. The writer is not endeavoring to contend that a combination that was organically illegal in I902 can necessarily cure its illegality by dealing fairly with the public, by establishing fair prices and by permitting its competitors to live. He does assert, however, that the basis for the presumption that a monopoly exists from the fact that the combination was made, apparently in restraint of trade, is swept away when it is shown by years of experience that none of the acts that were contemplated or feared have taken place. 
The second reason advanced for dissolution of the company was that given by Justice Hook, namely, "that the company was not a result of normal growth or the fair enterprise of an individual, a partnership or a corporation." He was not particularly concerned as to whether the contract of I902 violated the law or not. What impressed him most was that five large companies had gotten together. Everything else, he declared, was mere detail.

It is submitted that the distinction that has existed in the minds of a number of lawyers and judges between the business which is the result of so-called natural growth and development and that which is the result of a combination of a number of going concerns has, neither in law nor in economics, any sound basis. In the first place it is very difficult to say what is meant by natural growth or development. A smaller business may assume or may buy at a bankruptcy sale the good-will of one of its former competitors. It may add to its capital or increase its output by taking in a new partner and in this way open up a new factory from time to time; or two men who have been engaged in the same business heretofore may enter into a partnership and join their respective businesses. All this is commonly regarded as natural growth and development but nevertheless in each instance the capital has been added and the business increased by the enterprise not of an individual. Even smaller business men have been known to make contracts to divide territory, to maintain prices, to limit their output and to have blacklists. It is only when these acts become the acts of large units that attention is attracted to them and the public thinks of combinations and speaks of restraint of trade. Smaller combinations have been going along side by side with the bigger ones, only in greater number. They have countenanced the same methods of doing business that have been pursued by the so-called trusts. These smaller business men have been forced to combine, for they discovered that competition is not the life of trade but that there generally goes with it a strangling process that stults growth, checks expansion and spells failure and ruin if carried to its ultimate conclusion.

There seems to be an impression that only big business has coerced the small business man. However, it is probably not too venturesome to say that small business men themselves have forced out of business and coerced their small competitors to a greater extent than the big combinations have done. Big 
business at least has felt the restraint of being constantly in public view and subject to daily criticism. When one small business man has forced another out of business by unfairly underselling him and then finally takes over that business, can it be said that that is the result of fair enterprise? But, irrespective of the difficulty of ascertaining what can be said to be the result of fair enterprise, we are still met with the point that it is impossible to say what possible difference there can be whether any particular organization, no matter how big it may be, is the result of fair enterprise of an individual or a group of individuals or whether it is the result of the combination of a number of corporations. Suppose that the McCormick Company, one of the individual component parts of the International Harvester Company, had succeeded in forcing out the other large four competing companies and gradually had absorbed their business so that they covered the same territory as the International Harvester Company does to-day, what difference would there be so far as the public welfare or the interpretation of the Sherman Act may be concerned? Though the Sherman Act states that every contract, combination in the form of trust or otherwise is declared to be an illegal combination in restraint of trade, we must admit that were this language carried to its last analysis it would so tie the hands of business men as to almost put an end to all growth.

Thus in the Keystone Watch Case the court said:

"Section 2 gives us no help, for "any" part, if strictly construed, might range from a minute and inconsiderable fraction to a part just less than the whole. If, therefore, a merchant, either an individual or a corporation, by the most commendable zeal and industry should succeed in diverting to himself a very small part of a competitor's business, he would be monopolizing a "part" of the trade, and would be condemned by the letter of the act. And in like manner, if the statute is using the strict meaning of "restraint of trade," no merchant could act in combination with his own partner, in successful competition for part of a rival's business, even by the fairest and most honorable means, except at the risk of "restraining" trade. Further examples are needless; many more might be given. Clearly, therefore, as it seems to us, the act could not have been intended to bear a meaning so subversive; and it seems plain that the supreme court was abundantly justified in turning to the rule of reason, and in holding that of necessity congress must have been dealing with 
undue or unreasonable restraints of trade, whether such restraints take the form of monopolies in whole or in part, or of concerted action under any guise whatever." (p. 516.)

It is submitted that this reasoning is correct and conclusive. It demonstrated that only a broad and liberal interpretation of Section 2 of the act prevents thousands of minor transactions from being held to be contracts in restraint of trade. And it shows that there is not sufficient justification for the holding of a court that a business which is the result of the combination of integral units is in itself sufficient ground for condemning it as illegal or dissolving it. For many a business, apparently the result of the enterprise of an individual, has become large and strong through many contracts that it has entered into in the past restraining trade.

Size, according to Judge Hook, becomes a menace only when it is the result of combination. If size, however, is a menace, it must be so irrespective of combination; and if size on the other hand is not a menace, then nothing can make it become so because it is the result of combination. In spite of statutes, the courts will ultimately find a reason for permitting combination where the public welfare is not hurt. And should any industry fall into the hands of an individual and threaten the public welfare, either the courts or congress will ultimately find a means of holding it in check. In other words, in the last resort, the forum for determining these questions will be this public and the sole consideration will be whether the public welfare has been benefited or deterred.

Another reason why the decree of dissolution seems to be extremely harsh is that, for a long while, both lawyers and courts have been struggling to ascertain what the Sherman law means and how it should be interpreted. As pointed out, this interpretation, in the writer's opinion, must ultimately square with the economic necessities of the day. But confessedly during that period, it has been a guess what contract or what act would be regarded as inhibited by it, and if any act is so vague that its meaning cannot be ascertained, the court should be careful before it destroys the organization that in good faith attempted to comply with it. There is no charge anywhere in the Harvester decision that the organizers were conscious of a violation of any law. Had the company during its history been guilty of oppressive acts and had been a menace to the public, 
then it might be urged that no leniency should or ought to be asked because of its inability to have comprehended the meaning of the act. But where the public has not been harmed, such a decree is a blow struck at business; the economic efficiency of the country is halted, progress is stayed. We may feel that courts should adopt a less harsh remedy where a company during its history had been free from such oppressive business tactics. This was accomplished in both the Keystone Watch Case and the Great Lakes Towing Case, supra, though in each instance the corporations had been guilty of far more oppressive tactics than in the Harvester case. In those cases, the court came to the conclusion that the defendants should be enjoined from pursuing their coercive methods and the court specifically found that no benefit would accrue to the country at large by entering a decree to dissolve these companies. If this result should obtain in two cases where the defendant was less entitled to mercy than in the Harvester case, it seems that it would only be fair to extend the same leniency to that company. There is all the more reason why this method of relief should obtain; should it not bring about the results desired, a trust could always later on be dissolved.

Is this not a saner conclusion than immediately decreeing a dissolution? Should, for any reason, an injunction not correct the conditions, a corporation could always thereafter be dissolved. A dissolution once effected could only at a serious cost be repaired. Economists tell us the more efficient an industry, the more highly it is organized, the better it is for the entire community. Surely, then, courts should only as a last resort wipe out the efficiency of an industry that a dissolution necessarily carries along with it.

The court that attempts to solve these great questions on purely legal reasoning and bases its opinion on the intricacies and niceties of the law is on the way to decisions that will not give satisfaction. There is much reason to believe that the courts recognize that there is necessity for a broader and more comprehensive way of dealing with these questions. Law-books and precedents contained in them will not satisfy. It is impossible to ascertain from them the economic knowledge it is necessary to have in order to be able to say what may or may not be for the public benefit. Each one of these decisions should be more or less of an economic brief as to the policy of this country in dealing with great business organizations. In other 
words, the question of what is a monopoly and the question of what is a reasonable restraint of trade must be looked upon more in the light of pure economic reasoning.

So it may be doubted whether decisions will give thorough satisfaction unless economists and judges are drawn more closely together; unless courts are willing to pay more heed to what the economists have to say on these vital questions. Thus, to revert to the Harvester decision, the court assumed that because the company controlled about eighty per cent of the output of certain agricultural machines, though competition had remained free and open, and though the business of their competitors had grown, nevertheless the mere fact that it had such a big percentage of the business made the Harvester Company as to those products a monopolist. It is interesting to note that while there is some dispute on this point, the foremost economists in the country feel that this economic doctrine is entirely incorrect.

In order to ascertain their views on the subject a query embodying this point was put to a number. In reply thereto, the following answers. were received:

Arthur T. Hadley answered by saying:

"I can only make the obvious answer that the possession of sixty-five or even eighty-five per cent of the trade does not necessarily create economic monopoly; but that the larger the percentage controlled by one concern, the greater is the presumption which its defenders have to rebut, and the larger the chance that a monopoly may in fact exist."

\section{J. Lawrence Laughlin answered by saying:}

"The percentage of business done is aside from the point. If there is no obstruction to competition, and an industrial organization succeeds in gaining the major part of the trade, it is direct evidence of its superior efficiency. That means that any other competitor, showing at any time superior efficiency, can take the trade away from it."

Jeremiah W. Jenks answered by saying:

"I should reply that in my judgment, a corporation cannot be considered a monopoly from an economic viewpoint if its competitors are in the field as freely as is the corporation and there is no obstruction to other competitors entering the field. Second, under these circumstances, the possession of even eighty-five per cent of the trade in the 
particular line under consideration does not give an economic monopoly."

F. W. Taussig answered by saying:

"I suppose the ground upon which an economist might defend such a decision as that of the district court in the Harvester Case, is that there is danger of monopoly conditions and monopoly prices when one concern controls seventy or eighty per cent of the output. Like almost all questions, this must be decided not according to what has happened in a particular case, but according to the trend to be ordinarily expected. Now, we simply do not know with any certainty, even with an approach to certainty, whether such commanding control means 'unreasonable' prices and monopoly profits. Something of that sort seems to have happened in other cases of commanding control; but whether it would happen again in the future, with the stamping out of unfair competition, I should not venture to say."

Jacob $\mathrm{H}$. Hollander answered by saying:

"An industry is naturally monopolistic when it tends by the superior profitableness of large scale production to grow in size at the expense of its competitors, and this without any illegal preferential advantage granted it, and without resort to methods and practices at variance with prevailing business standards."

"It seems to me entirely consonant with a sound social policy to tolerate the increase in relative size of such a business unit and indeed the wisdom of attempting to arrest its growth by legislative prohibition may be questioned. On the other hand, it will be readily inferred from the foregoing that when the monopolistic tendency results from illegal discrimination or from unwholesome business methods, such growth is undesirable."

If there were discrimination, in other words, or unwholesome business methods, such as Mr. Hollander refers to in his answer, or. were there unreasonable prices and monopoly profits, as Professor Taussig suggests in his answer, then from the point of view of an economist the government would be warranted in interfering. However, apparently all the economists agree that the mere fact that an organization has from seventy to eighty per cent of the volume of business in its line, as long as its profits are not unwarranted and there is a free open field to other competitors, does not make it a monopoly. When one considers how far reaching a dissolution may be, the many 
interests that are at stake, the great disorganization of industry resulting, the uncertainty that such dissolution gives to commercial enterprises, such a decree should not be lightly entered and particularly does the excuse vanish when the only reason for it is based not upon public welfare but because of a technical legal violation that took place a decade before the suit was brought.

The days of uncontrolled competition are gone. With their passing, waste and extravagance in business have been checked. The courts have held that restraint and combination to a reasonable degree are proper and legal. Judging from the criticisms of the International Harvester Case, the public not only has accepted this doctrine, but also has come to be opposed to a dissolution of big business units unless the people at large have been harmed. May we not hope that the courts in the future in determining the degree of restraint or combination that shall be permissible, will turn to the economists and solve these intricate problems with their aid on a scientific basis. A sane policy relating to big business will thus be evolved. The main consideration will not be whether an illegal act was committed a decade or more ago; it will not be whether a company represents the natural development of an individual or a group of individuals; the only consideration will and should be what is for the public good.

Chicago, Irr.

Herbert J. Friedman. 